\title{
First Report of the Mantid Shrimp Faughnia formosae (Stomatopoda: Parasquillidae) from Korea
}

\author{
Hee-seung Hwang, Sang-kyu Lee, Mijin Kim, Won Kim* \\ School of Biological Sciences, Seoul National University, Seoul 151-747, Korea
}

\begin{abstract}
The stomatopods are aggressive predatory marine crustaceans, which are mainly found in tropical and subtropical regions. Among these, a parasquillid stomatopod, Faughnia formosae Manning and Chan, 1997, collected from Jeju Island, is reported for the first time in Korea. The family is easily distinguished from other families by the presence of an asymmetrically bilobed cornea, stout propodus on the raptorial claw, and three primary spines of the uropodal protopod. In the paper, detailed descriptions and illustrations of this species are provided alongside a photograph. A key to the species of Korean mantis shrimp is also presented. As a result of this study, four species of stomatopods including this species are now recorded in Korean fauna.
\end{abstract}

Keywords: Crustacea, stomatopoda, Parasquillidae, Faughnia, mantis shrimp

\section{INTRODUCTION}

The stomatopods, commonly called mantis shrimp, are aggressive predators which are found in tropical and subtropical regions (Ahyong, 2001). Large and powerful raptorial appendages, which can be used by 'smashing' or 'spearing', are their trademark morphological feature (Caldwell and Dingle, 1976).

More than 450 stomatopod species have been described worldwide (Ahyong, 2001), of which only 3 species have previously been recorded in Korean waters: Oratosquilla oratoria (De Haan, 1844), Taku spinosocarinatus (Fukuda, 1909), and Chorisquilla spinosissima (Pfeffer, 1888) (see Kim and Rho, 1969; The Korean Society of Systematic Zoology, 1997). They inhabit holes in the sandy and muddy bottoms at depths between 20-90 m subtidal zones ditstributed to coastline of South Korea (Hong et al., 2006). The present species, Faughnia formosae Manning and Chan, 1997, is newly recorded from Korea and the genus Faughnia Serène, 1962 and the family Parasquillidae Manning, 1995 are also reported for the first time from Korean waters.

The specimen was collected from the subtidal zone of Jeju Island by fishing net, and was preserved in $95 \%$ ethyl alcohol.
A steromicroscope (MZ8; Leica, Wetzlar, Germany) was used for observation and sorting. Images were recorded using a digital camera (Model D7000; Nikon, Tokyo, Japan). Body length, or total length, was measured along the dorsal midline from the apex of the rostral plate to the apices of the submedian teeth of the telson. Morphological terminology is mostly after Ahyong (2001). Specimen examined herein has been deposited in the Marine Arthropod Depository Bank of Korea (MADBK), Seoul National University.

\section{SYSTEMATIC ACCOUNTS}

Order Stomatopoda Latreille, 1817

$1 *$ Family Parasquillidae Manning, 1995

${ }^{2 *}$ Genus Faughnia Serène, 1962

\section{${ }^{3 *}$ Faughnia formosae Manning and Chan, 1997}

(Figs. 1, 2)

Pseudosquilla empusa: Komai, 1927: 325, 346, fig. 1; Dong et al., 1983: 90, fig. 3 [not Squilla empusa de Haan, 1844].

Faughnia formosae Manning and Chan, 1997: 546-551, figs. 1-4; Moosa, 2000: 422; Ahyong and Naiyanetr, 2002: 289.

Korean name: ${ }^{1 *}$ 돌기갯가재과 (신칭), ${ }^{2 *}$ 돌기갯가재속 (신칭), ${ }^{3 *}$ 다섯돌기갯가재 (신칭)

(c) This is an Open Access article distributed under the terms of the Creative Commons Attribution Non-Commercial License (http://creativecommons.org/ licenses/by-nc/3.0/) which permits unrestricted non-commercial use, distribution, and reproduction in any medium, provided the original work is properly cited.

pISSN 2234-6953 eISSN 2234-8190
*To whom correspondence should be addressed

Tel: 82-2-880-6695, Fax: 82-2-872-1993

E-mail: wonkim@plaza.snu.ac.kr 


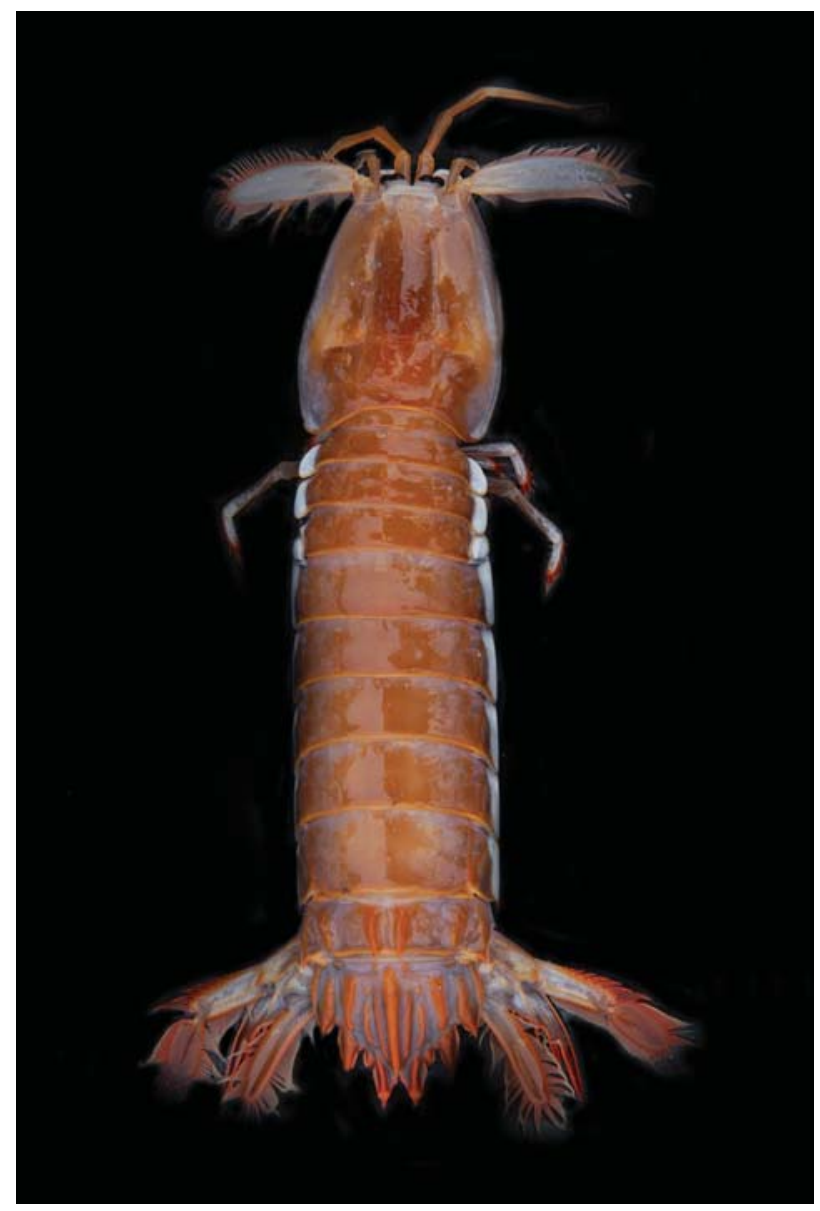

Fig. 1. Faughnia formosae Manning and Chan, 1997, male. Whole animal, $132 \mathrm{~mm}$.

Material examined. Korea: $1 \sigma^{\nearrow}$, Jeju Island, Seogwipo-si, Daejeong-eup, Hamori, Moseulpo port, 10 Sep 2006, by fishing net.

Description. Body (Fig. 1) approximately cylindrical; dorsal surface overall pitted and smooth; articulation compressed.

Eye (Fig. 2A) not reaching to end of first segment of antennular peduncle. Cornea asymmetrically bilobed, outer margin longer than inner.

Carapace (Figs. 1, 2A) with indistinct reflected marginal carina; anterolateral angles rounded, not produced anteriorly.

Rostral plate (Fig. 2A) without long apical spine, width 2.6 times longer than median length.

Raptorial claw (Fig. 2B) stout; ischio-meral articulation terminal; dorsal margin of carpus with 2 blunt teeth; occlusal margin of propodus with 3 movable spine and a series of dense pectinations; dactylus slender, bearing 3 teeth on inner margin.

Sternal keel of eighth thoracic somite (Fig. 2C) rounded.

Lateral processes of sixth to eighth thoracic somites (Figs.
$1,2 \mathrm{D})$ broadly rounded, with low ridge; that of seventh slightly wider than sixth.

Endopod of first male pleopod (Fig. 2E) bearing posterior endite.

Telson (Fig. 2F) as long as broad, with 3 pairs of primary teeth (submedian, intermediate, lateral); with 2 spiniform intermediate denticles, 1 spiniform lateral denticle. Dorsal surface with median carina and 5 pairs of longitudinal carinae (accessory median, anterior submedian, and lateral slightly interrupted, anterior intermediate and marginal uninterrupted) in addition to carinae of all primary teeth extending onto surface of telson. Ventral surface of telson smooth, without postanal carina.

Posterolateral angles of fourth to sixth abdominal somites (Fig. 2G) bearing low lateral, marginal carinae, except for submedian; sixth somite with spinule produced ventrolaterally.

Uropod (Fig. 2H) with exopod having 8 movable spines; protopod bearing well-developed spinules, outermost largest, flanked proximally by 4 smaller spinules as well as some denticulation on inner margin.

Distribution. Japan, Taiwan, the Philippines, Thailand, and Korea (Jeju Island).

Coloration. Color in life mostly dark-orange, with antennules, most of carapace, thoracic and abdominal somites, telson largely dark-orange. Antennal scales, rostral plate, lateral margins of carapace, pereiopods, and most of uropods whitish; lateral processes of thoracic somites and lateral margins of abdominal somites distinctly white, appearing as a pair of white bands along the body. Tips of pereopod, and movable spines, as well as distal segment of uropodal exopod reddish orange.

Remarks. The present species, Faughnia formosae is the first record from Korean waters. According to the original description of Manning and Chan (1997), F. formosae is easily distinguished from allied species by the following characteristics: 1) five pairs of carinae on the telson, and 2) well developed spinules on the inner margin of the uropodal protopod. The present specimen agrees well with the original description, except that the width of the rostral plate was 2.6 times as long as the median length in the present specimen, whereas width was only 'more than twice median length' in the original description.

\section{Key to the species of Korean mantis shrimps}

1. Telson with at least 4 densely arranged intermediate denticles. Median carina of carapace distinct, not interrupted at base of anterior bifurcation. Lateral process of fifth thoracic somite bilobed …......... Oratosquilla oratoria

- Telson with no more than 3 intermediate denticles. Median carina of carapace indistinct. Lateral process of fifth tho- 

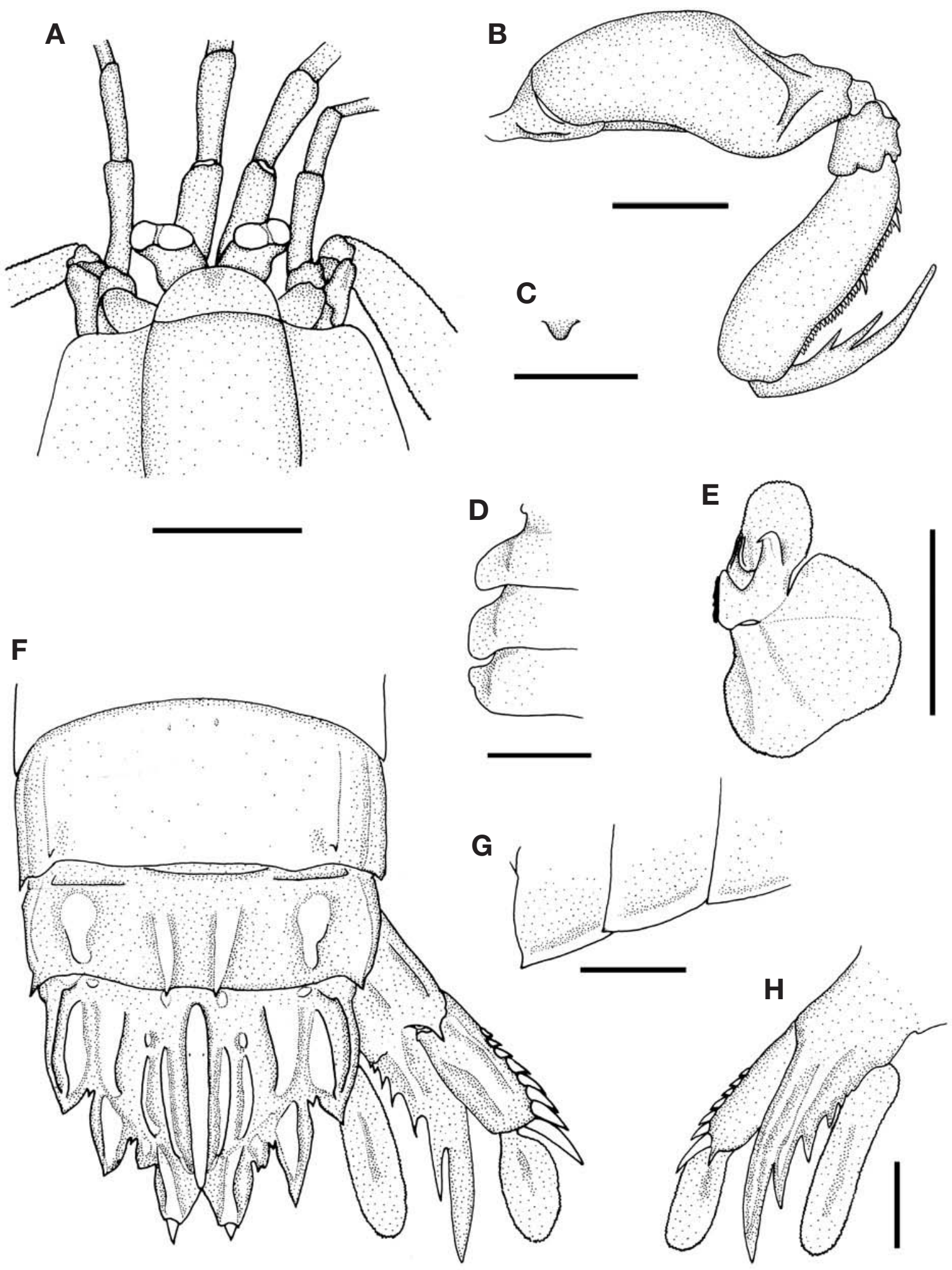

Fig. 2. Faughnia formosae Manning and Chan, 1997, male. A, Anterior cephalon; B, Raptorial claw; C, Sternal keel of eighth thoracic somite, right lateral; D, Lateral processes of sixth to eighth thoracic somites; E, Endopod of first male pleopod; F, Fifth to sixth abdominal somites, telson, and uropod; G, Posterolateral angles of fourth to sixth abdominal somites; $H$, Uropod, right ventral. Scale bars: $A, B, D-H=10 \mathrm{~mm}, C=20 \mathrm{~mm}$. 
racic somite entire, rounded 2

2. Protopod of uropod bearing three primary spines. Cornea asymmetrically bilobed. Dorsal surface of telson with median and 5 pairs of longitudinal carine

Faughnia formosae

- Protopod of uropod bearing one or two primary spines. Cornea symmetrically bilobed. Dorsal surface of telson without 5 pairs of longitudinal carinae 3

3. Exopod of uropod bearing stout, anteriorly recurved distal spines on outer margin. Dorsal surface of telson without long spines Taku spinosocarinatus

- Exopod of uropod bearing slender, straight distal spines on outer margin. Dorsal surface of telson entirely with long spines Chorisquilla spinosissima

\section{ACKNOWLEDGMENTS}

This study was in part supported by a grant from the National Institute of Biological Resources (NIBR), funded by the Ministry of Environment (MOE) of the Republic of Korea. (NIBR No. 2013-02-001), and by a grant from the Marine Biotechnology Program, funded by Ministry of Land, Transport and Maritime Affairs of the Korean Government.

\section{REFERENCES}

Ahyong ST, 2001. Revision of the Australian stomatopod Crustacea. Records of the Australian Museum, Supplement, 26: 1-326.

Ahyong ST, Naiyanetr P, 2002. Stomatopod crustaceans from
Phuket and the Andaman Sea. Phuket Marine Biological Centre Special Publication, 23:281-312.

Caldwell RL, Dingle H, 1976. Stomatopods. Scientific American, 234:80-89.

Dong YM, Chen YS, Huang LQ, 1983. Report on the stomatopods of the East China Sea. Donghai Marine Science, 1:8298.

Hong SY, Park KY, Park CW, Han CH, Suh HL, Yun SG, Song CB, Jo SG, Lim HS, Kang YS, Kim DJ, Ma CW, Son MH, Cha HK, Kim KB, Choi SD, Park KY, Oh CW, Kim DN, Shon HS, Kim JN, Choi JH, Kim MH, Choi IY, 2006. Marine Invertebrates in Korean Coasts. Academy Publishing Company, Seoul, pp. 1-479.

Kim HS, Rho BJ, 1969. The seashore marine fauna of Chuja Islands, Korea. In: A report on the floral and faunal survey of Chuja Island (Ed., Office of Cultural Properties, Korea Ministry of Culture and Information). Office of Cultural Properties, Korea Ministry of Culture and Information, Seoul, pp. 67-108.

Komai T, 1927. Stomatopoda of Japan and adjacent localities. Memoirs of the College of Science, Kyoto Imperial University, Series B, 3:307-354.

Manning RB, Chan TY, 1997. The genus Faughnia from Taiwan, with the description of a new species (Stomatopoda: Parasquillidae). Journal of Crustacean Biology, 17:546-554.

Moosa MK, 2000. Marine biodiversity of the South China Sea: a checklist of stomatopod Crustacea. The Raffles Bulletin of Zoology, Supplement, 8:405-457.

The Korean Society of Systematic Zoology, 1997. List of animals in Korea (excluding insects). Academy Publishing Co., Seoul, pp. 1-489.

Received February 21, 2013 Revised May 13, 2013 Accepted May 20, 2013 